\title{
WestVirginiaUniversity
}

THE RESEARCH REPOSITORY @ WVU

Graduate Theses, Dissertations, and Problem Reports

2011

\section{Immediacy and Gesture}

\author{
Aaron Anslow \\ West Virginia University
}

Follow this and additional works at: https://researchrepository.wvu.edu/etd

\section{Recommended Citation}

Anslow, Aaron, "Immediacy and Gesture" (2011). Graduate Theses, Dissertations, and Problem Reports. 2200.

https://researchrepository.wvu.edu/etd/2200

This Thesis is protected by copyright and/or related rights. It has been brought to you by the The Research Repository @ WVU with permission from the rights-holder(s). You are free to use this Thesis in any way that is permitted by the copyright and related rights legislation that applies to your use. For other uses you must obtain permission from the rights-holder(s) directly, unless additional rights are indicated by a Creative Commons license in the record and/ or on the work itself. This Thesis has been accepted for inclusion in WVU Graduate Theses, Dissertations, and Problem Reports collection by an authorized administrator of The Research Repository @ WVU. For more information, please contact researchrepository@mail.wvu.edu. 


\title{
Immediacy and Gesture
}

\author{
Aaron Anslow \\ Thesis submitted to the \\ College of Creative Arts \\ at West Virginia University \\ In partial fulfillment of the requirements \\ for the degree of \\ Master of Fine Arts \\ In \\ Ceramics
}

Division of Art

Shoji Satake

Robert Moore

Dylan Collins

Joseph Lupo

Morgantown, WV. 2011

Keywords: Ceramics, Pottery, Wood Firing, Salt Firing, Form, Hand building, Atmospheric Firing, Molds, Material, Process 


\section{Abstract \\ Immediacy and Gesture}

\section{Aaron Anslow}

The concepts of immediacy and gesture are described in this thesis and their relation to my ceramic work. This thesis also discusses the historic and contemporary influences that contribute to my work, as well as my personal history, travel, and technical research into different clay bodies, slips, glazes, and firings. 


\section{Acknowledgements}

I would first like to thank Bob Anderson for allowing me to be a part of this program, for an unforgettable trip to China, and all of the hours of conversation and counsel. Thank you for your hospitality, friendship, and taking the time to teach me about ceramics.

I would like to thank my committee; Shoji Satake, Robert Moore, Jennifer Allen, Dylan Collins, and Joe Lupo for their mentoring. Thank you for being honest even though I did not always want to hear it. I appreciate the candid criticism and guidance that you have provided. Thank you for helping me to become a better artist.

One of the greatest resources in graduate school has been my fellow classmates. I would like to thank all of my peers for criticism, pointers, and friendship. I will always cherish the people and the clay community that I have had the honor to work with at West Virginia University.

Most importantly I would like to thank my wife Kristin for enduring my frequent absences, late nights, missed dinners, and my personal frustrations with graduate school. This would have been much more complicated without your support and counsel. 


\section{Table of Contents}

• Abstract .................................................................................... ii

• Acknowledgements ..................................................................... iv

• Introduction.................................................................................. 1

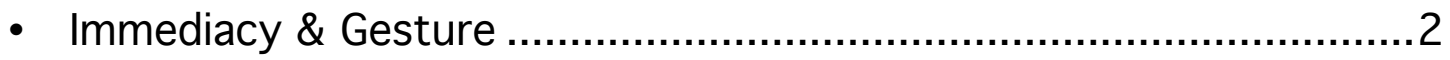

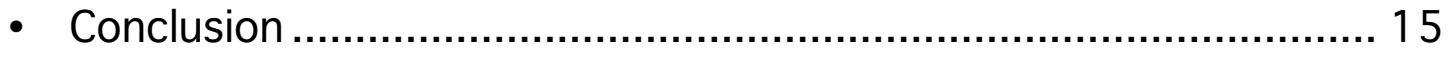

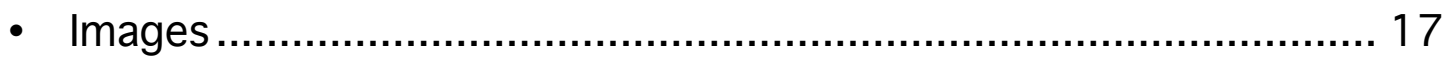

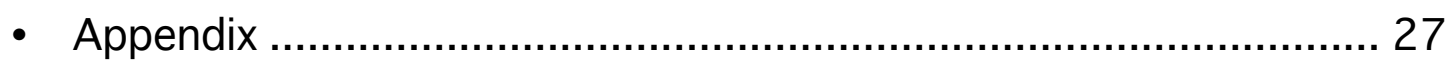

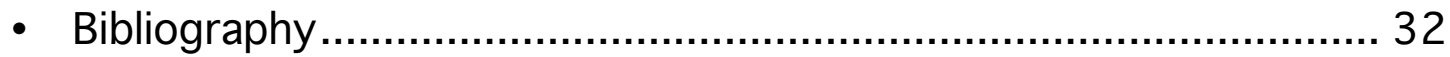

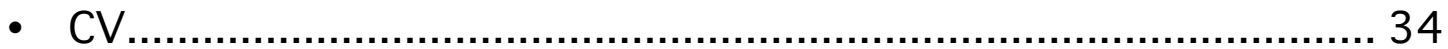




\section{Introduction}

Studying ceramics has allowed me to connect to past and present ceramic artists, different cultures, and has become my outlet for selfexploration. Since arriving at West Virginia University, I have had the opportunity to work with a variety of processes and techniques that have fueled my interests in ceramics and its endless possibilities. This thesis discusses my personal history, ceramic influences (both historic and contemporary), as well as my trip to China, which greatly impacted the work.

In relation to the development of my work, one of the most influential components of the West Virginia Ceramics Studio is its production program. Introduction into the different processes and tools of the production facilities afforded my first experiences with the use of plaster molds and many other industrial techniques. Production methods taught me about efficiency and the importance of learning through the creation of multiples. However, with my work I use molds to produce differing and individual pieces, instead of reproducing multiples of the same objects. 
The pieces speak about the immediacy and responsiveness that the material of clay makes possible. This is due to its malleable nature, during the process of construction. Clay is an amazing material that records every touch. As each piece is constructed, it captures the act of making by showing stretch marks from conforming to the force of being dropped onto molds, and impressions made by tools and hands. These traits communicate the action and energy of the forming process. It is important for me to translate the soft gestural qualities, and liveliness of the clay in the finished pieces.

Immediacy plays a major role in my process. The pieces are handbuilt using molds to capture the quick and gestural qualities in the formation of the different pieces. I want the work to retain the soft nature of clay during the forming process. The use of atmospheric kilns allows me to obtain surfaces that reference natural materials, such as rock and stone, which relate well to the overall forms.

\section{Immediacy \& Gesture}

The work revolves around the immediacy and gesture of process and conceptual ideas about the vessel. Though the objects that I make can be used, utility is not my primary goal. In keeping manipulation of the clay body to a minimum when making the forms, and striving to allow the 
variety of creases and seams that result from the forming process, I am able to communicate the intrinsic features of the clay more successfully. My goal is to show the raw beauty of the clay body, and the different textures resulting from unintentional occurrences during the creation process. These acts make apparent the concepts of immediacy and gesture.

The use of common forms such as plates, vases, and bowls stem from my love of utilitarian pottery and childhood memories of seeing my mother work in the kitchen with old mixing bowls and plates. My pieces begin with the idea of domestic utilitarian forms, and are transformed into more conceptual vessels that are heavy both visually and physically. I aim for the pieces to speak of the vessel, partly because it is such an important part of my history. The forms reference utility through the internal space, but the exterior form greatly contrasts usable pottery, and begs the question: What is utility? The size and weight of the pieces also emphasize the importance of the object over its functionality.

It must always be remembered that the dissociation of use and beauty is a purely arbitrary thing. It is true that pots exist which are useful and not beautiful, and others that are beautiful and impractical; but neither of these extremes can be considered normal: the normal is balanced between the two. Thus in looking for the best approach to pottery it seems reasonable to expect that beauty will emerge from a fusion of the individuals 
character and the culture of the potter with the nature of his material $^{1}$

Another important aspect to my history is travel. During my undergraduate studies I was fortunate enough to travel to England and be exposed to English ceramics and Bernard Leach (1887-1979) (Figure 1). Leach played an important role in bridging Japanese and British ceramics. Through the friendship and work of Bernard Leach, Shoji Hamada, Kanjiro Kawai, and philosopher Soetsu Yanagi, founded the Mingei movement (this movement celebrates Japanese folk art)². In 1952, Hamada and Leach traveled to Helena, Montana to Western Clay Manufacturing $\mathrm{Co}^{3}$. now know as the Archie Bray Foundation and helped shape the future of American ceramics. Peter Voulkos (1924 -2002) (Figure 2) was one of the resident directors of the clay company at that time. Voulkos has influenced countless artists throughout his career including myself. To use the words Collette Chattopadhyay used while describing Voulkos's work: "Allowing glimpses of the dynamics of what occurs in the studio, the

${ }^{1}$ Bernard Leach, A Potter's Book. (London, England: Clays Ltd., 1976), 18.

${ }^{2}$ Mingei Legacy: potters Shoji Hamada, Kanjiro Kawai, Bernard Leach, and their successors, Mingei International Museum, http://www.mingei.org/exhibitions/details/215(accessed April 27, 2011) 3 "History," Archiebrayfoundation, http://www.archiebray.org/about_us/abf_history.html (accessed April 27, 2011) 
works are filled with the residue of the creative act, metaphorical indexes to the artistic path trod between intention and chance." 4

Voulkos handled clay in an aggressive and immediate way that would leave a lively and energetic finished piece. The manner in which Voulkos pushed the idea of the conceptual vessel inspires me to continue to make, because as Voulkos so simply states: "I get down to the very basic forms that I really love, but they are still giving me information." ${ }^{5}$ Other artists such as Joe Pintz (Figure 3) and Tim Rowan (Figure 4) impart some of the characteristics I am drawn to. Joe Pintz's objects have a rough handmade quality rooted in the agrarian tradition. These objects include troughs, baskets, bowls, and tools that speak of wear, time, and use. He hand-builds with molds and refines the forms with a rasp. He also uses simplistic glazes with distressed looking surfaces. Pintz describes his reasons for doing so as such: "People often begin to grasp the significance of objects when they are lost, broken or worn out. For this reason, I choose weathered surfaces and faded colors that suggest

\footnotetext{
${ }^{4}$ Collette Chattopadhyay. "Peter Voulkos: Clay, Space, and Time," International Sculpture Center, Http://www.Sculpture.org/documents/scmag01/march01/voulkos/voulk os.stml 5 "Peter Voulkos," Ground Floor Sculpture. http://www.sculpture.org/documents/scmag01/march01/voulkos/voulk os.shtml (accessed April 26th, 2011)
} 
use." ${ }^{6}$ While I value Pintz's attempt at conveying the importance of time, I am striving to express the beauty of the natural surface more so than an appreciation of the object in reference to time.

Another artist who shares ideas similar to mine, in both form and concept, is Tim Rowan. His sculptural work speaks of time in a geological sense. His work has the appearance of being decayed by time resembling weathered stone, and rusty mechanical objects. Rowan remarks that, "There is one thing that we know for certain... as biological organisms eventually our bodies will no longer be "alive". We cannot escape the forces of time."7 Rowan's surfaces seek to express the decay and breakdown of materials over time. I am drawn to these same surfaces, and I also hope to capture the moment of creation, and the beauty to be found in the liveliness of natural surfaces through their constant change, more so than their decay.

As well as being influenced by my trip to England and contemporary artists I continue to find myself influenced by the many people I encountered and experiences I had while in China. It was a truly humbling experience. I was most drawn to pottery of Mr. Jin, of Tian Bao, which is

6 “Joe Pintz at MudFire," MudFire. http://www.mudfire.com/joe-pintzconstructed.htm (accessed April 26, 2011)

7 "Tim Rowan Resume + Artist Statement," Tim Rowan, http://www.timrowan.com/index.html (accessed April 26, 2011) 
primarily made from a high iron, rough, unrefined clay body. The objects include roofing tiles, water jars, and other everyday pottery, which have after firing has a dark rich color and sandy texture.

I was equally interested in the saggars that are used to protect glazed ware. The saggars are clay boxes that glazed pieces are put into to protect them from the atmosphere of coal and wood kilns. Usually the saggars are of little importance besides protecting glazed ware, but I found their coarse surfaces just as intriguing and beautiful as the glazed ware. The rough, unrefined, and natural qualities of these surfaces directly influence some of the surfaces I strive for in my work (Figure 5).

While in China I also spent time with Takeshi Yasuda, Japanese born, British potter (b. 1943). (Figure 6) He was the Director of the Pottery Workshop's Experimental Factory in Jingdezhen ${ }^{8}$ at the time. I was drawn to Takeshi's work because of its potential to convey the soft material attributes of clay. David Hamilton (b. 1933), a British Photographer wrote: “The prospect of someone coming to Takeshi Yasuda's work for the first time: the material presence, the way it is thrown and shaped and the sensuality of the formal language are to be physically experienced,

\footnotetext{
8 "Takeshi Yasuda," Takeshi Yasuda, http://takeshiyasuda.com/Takeshi_Yasuda_CV.pdf (accessed April 26, 2011)
} 
handled if possible and then contemplated at leisure." ${ }^{9}$ Yasuda taught me to be conscious of every touch, every tool used, and everything that could affect my studio practice. I became unencumbered, more responsive, and had greater focus on the tools I used in my work. I could now see how every movement made a different mark, and how the consistency of the clay yielded different surfaces. Due to this heightened awareness I became more aware of the interesting texture that objects such as cinderblocks and plaster molds provided (Figure 7).

Clay offers me an outlet for self-expression. It allows me to incorporate the construction skills I learned from my formative years. The physical act of taking a raw block of clay and manipulating it into a unique and beautiful object provides the constant opportunities to constantly create new forms and explore different surfaces.

I seek surfaces that reveal the process of making and speak of the decoration and firing methods. Whether I am brushing on slip or impressing objects into the wet clay, I want my process to be evident to the viewer. When the viewer is able to visualize how an artist works

\footnotetext{
9 “Takeshi Yasuda," Takeshi Yasuda, http://takeshiyasuda.com/Takeshi_Yasuda_CV.pdf (accessed April 26, 2011)
} 
through a piece I believe that experience brings the viewer and artist closer together.

The finished surfaces of my work speak not only to the immediacy of their creation and the beauty of gestural texture, but also give insight into the processes of loading, stacking, and firing. Atmospheric kilns, such as salt and wood, create surfaces that relate to the type of firing methods used. These kilns produce very directional firings that create diverse results in color and finish. I am also drawn to these types of firings, because they create characteristics that allude to a natural appearance.

These types of kilns both offer and relinquish some degree of the control in the finished surface. Flashing, orange peel, melting ash deposits, firing scars, and wad marks are all characteristics of salt and wood firings. These help create surface details that suggest an unrefined quality. Other factors such as clay bodies, slips, wood types, stacking, atmosphere, firing duration, glazes, and the amount of salt used all influence the end result. Researching such factors led me to realize the limitless possibilities that will continue to intrigue me.

Initially I experimented with wood firing. The ceramic surface captures and records the flow of the flame, which yields very dramatic 
results on each piece (figure 8) if stacked appropriately. Variation in colors include intense oranges, browns, and greens. The creation of these colors are affected by the works location in the kiln, the length of the firing, the type of wood used, and the firing's temperature, to name a few. (Figure 9) Although I am drawn to the results and processes of wood firing I found that in the interest of experimentation, it was more advantageous for me to move to a smaller kiln. The smaller kiln could be fired more readily, and this move introduced the possibility of new surfaces through the use of salt and soda.

Salt and soda kilns are similar to wood, in that the results rely on directional flow, and evidence of stacking and wadding are still relevant. A salt kilns yields surface variations that are both intriguing and beautiful, while lending to more consistent results than my experiences with wood firing. The surface quality can range from high gloss to matte. I used on average fifty pounds of salt for every twenty-five cubic feet of stacking space in the kiln. I use flashing slips that react to the amount of salt in the kiln. The kilns are fired to cone $10(2340 \mathrm{~F})$, which takes on average 12 hours to complete.

Firing with a soda compound can be a very active and exciting process. The amount of soda compound put into the kiln, and the manner 
in which it is introduced can greatly vary the finished surface. I experimented with sprayed soda, sawdust soaked in soda ash, and introducing salt directly into the kiln. I found that using rock salt was the most effective method of introducing the source of soda into the kiln atmosphere. The surfaces produced were varied, but indicated a strong sense of direction.

The form is equally as important as the surface in achieving the immediate and gestural qualities I admire. I utilized bisque, plaster, and wooden molds during formation of each form. In using molds, I am able to handle each piece less and prevent the clay from being overworked and contrived, while still capturing the creative energy. By limiting the amount of handprints that appear on the pieces they become less contrived and more organic. Molds also allow me the ability to create many unique pieces in a short amount time. Due to the thickness the pieces need extended periods of drying time. Drying can take up to three weeks depending on the size of the thickness. The drying time is only one of the challenges faced when creating such thick pieces out of clay.

Another challenge faced was severe cracking issues. After working through many different clay bodies I finally developed a clay body that allowed me to make these thick and heavy objects, while reducing the 
amount of cracking. The clay body consists of fireclay, grog, and sawdust, which creates a very strong structure. The added grog, which is a ground, fired ceramic, sand-like material, causes the body to shrink less and resist warping, and adds texture. The sawdust creates a more porous body, which allows for thicker pieces and a reduced risk of explosion and cracking in the kiln. The addition of sawdust and grog into the clay makes it harder to use, which makes using molds to produce the work necessary.

To begin a piece, start with solid pre-formed blocks of clay in simple forms like cones, cylinders, spheres, and cubes. I drop the clay onto a stationary mold. This ensures the work will not look labored, which makes for a much more interesting form. Through forming the clay on concrete blocks the texture of these blocks remains. Once the clay is dropped onto the mold the forms begin to capture the pulling effect of gravity (Figure 10). These details help to reveal the process in which the pieces are made, capturing the natural beauty of the clay and the action of making.

Although each piece I made in this first series appeared to be different they all had similar smaller scale. Because of this, the next challenge for me was to increase the size of these pieces and experiment with a new range of forms. As the forms grew in size I was forced to 
handle them differently. With an increase in weight, it became difficult not to leave unwanted characteristics such as handprints or distortion when handling the clay. As I made more of this work, I was able to decrease the amount of distortion and human imprints by using pieces foam to handle and maneuver the clay. Size and shape vary from piece to piece. The objects range from 3 " $\times 3$ " $\times 3$ " to 12 "x15" 12 " in size, and the weights from $4 \mathrm{lbs}$. to $50 \mathrm{lbs}$. The work successfully gives, the impression of visual weight that I strive for. To me, weight infers stability, comfort, which remind me of ceramic traditions of the past that I am inspired by.

Working through hundreds of pounds of clay helped me to refine the technique and produce many unique works of art. Variations in these gestural forms came from stacking simple shapes together and forming them over a mold (Figure 11). The elongated forms gave rise to variation and introduced taller and more elegant work (Figure 12) exposing the limitless possibilities for immediacy and gesture from these simple blocks of clay.

My clay body is made from Hawthorn fire clay is a course, refractory clay that can withstand high temperatures, and lends well to a more porous clay body. Therefore I use slips to vary and enhance the 
surfaces, and to create variety from piece to piece. Slips can add texture, mask the color of a clay body, and be used for decoration. The slips I use range from glossy to matte in finish and white to green in color. One such glossy slip is John Jessiman White ${ }^{10}$ stoneware (Figure 13). This is essentially a clay body mixed to the consistency of milk. The final result of this slip mimics that of a granite stone, with blushes of pink and pale yellow.

Another surface detail that plays an important role in the process and surface of each piece is the Wad marks. Wadding, is specialized clay used in atmospheric kilns, and is designed to resist the atmosphere while releasing from the objects. The wadding marks become a part of the finished piece (Figure 14), and along with the slip, and flashing come together to tell the story of how the object was stacked in the kiln.

At First I used traditional wadding made from equal parts of Kaolin and Alumina. I began to use seashells, which act as a type of natural wadding, due to my interested in Japanese wood fired ceramics. The seashells also leave unique marks created by the texture of each shell. Unsatisfied with shell marks I looked for another method. By mixing equal parts of whiting and plaster I was able to produce more unique firing

${ }^{10}$ See appendix p. 27 
marks. Throughout my research, some of the most interesting effects were located on the bottom of the form and caused by the wadding. This led me to stacking the forms on their sides to accentuate the blemishes and present them to the viewer rather than hiding them.

I find endless avenues to explore each time a kiln is fired. Being aware and paying attention to each and every move makes the beauty and capabilities of the natural material more obvious 


\section{Conclusion}

These objects showcase distortion and texture created from immediate and gestural qualities clay contains. Awareness of these qualities and process enabled me to find beauty in the natural traits of clay. The simple and textural surfaces characteristics help heighten the awareness of these natural qualities. By using tools like molds I am able to create unique objects that share the attributes of stone and other organic objects. Impurities and cracks only intensify these references.

Through various firings processes and construction methods the work conveys the idea of immediacy and gesture. The salt and wood kilns enhance these ideas along with the utilization, and variation in slip and glaze surfaces. These details allow the viewer to experience the work in the way I intend. 


\section{Images}

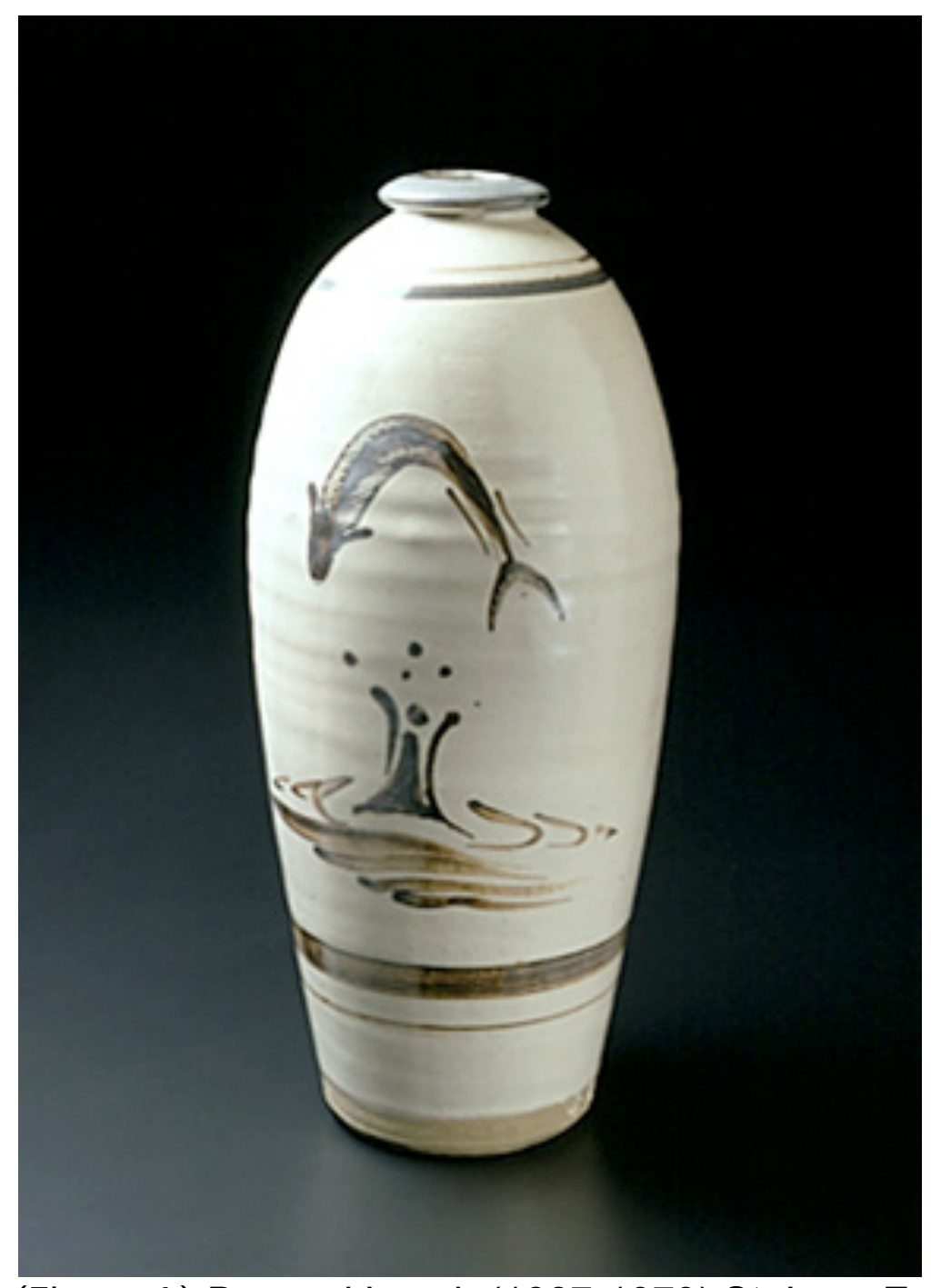

(Figure 1) Bernard Leach (1887-1979) St. Ives, English Vase with image of leaping salmon, 1957 Thrown stoneware with painted decoration14.5" $\mathrm{H} \mathrm{x}$ 6.25"Diameter http://www.newarkmuseum.org/assets/0/64/340/480/A6758F24044F-4C2A-9CE2-0D8DB0FECE6C.jpg 


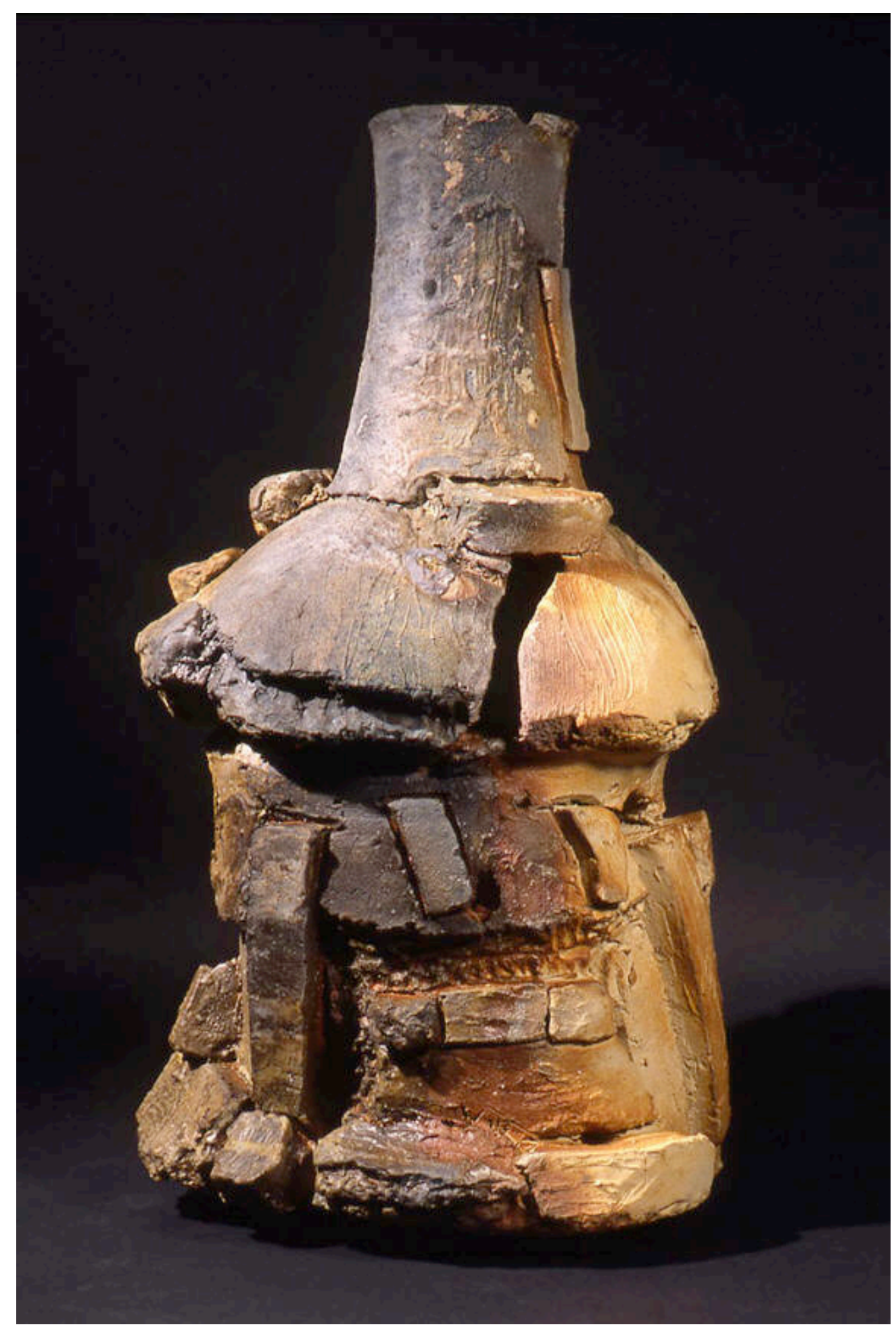

(Figure 2) Peter Voulkos, Siguirilla, 1999, Wood fired stoneware, $45 \times 24.5 \times 22$ in.

http://www.franklloyd.com/dynamic/images/detail/Peter_Voulkos_Siguiri lla_1999_2224_119.jpg 


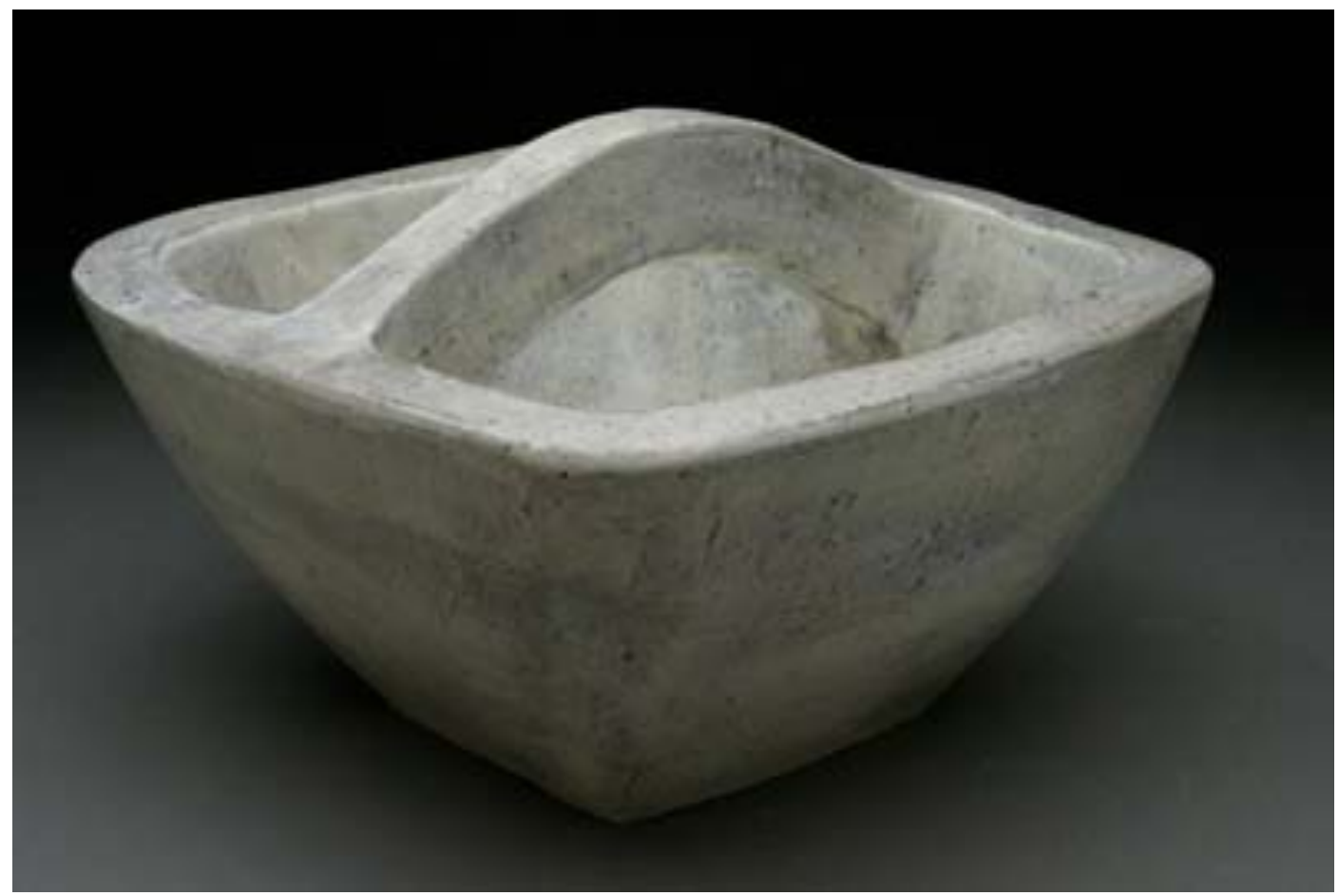

(Figure 3) Joe Pintz, http://www.mudfire.com/joe-pintz-constructed.htm

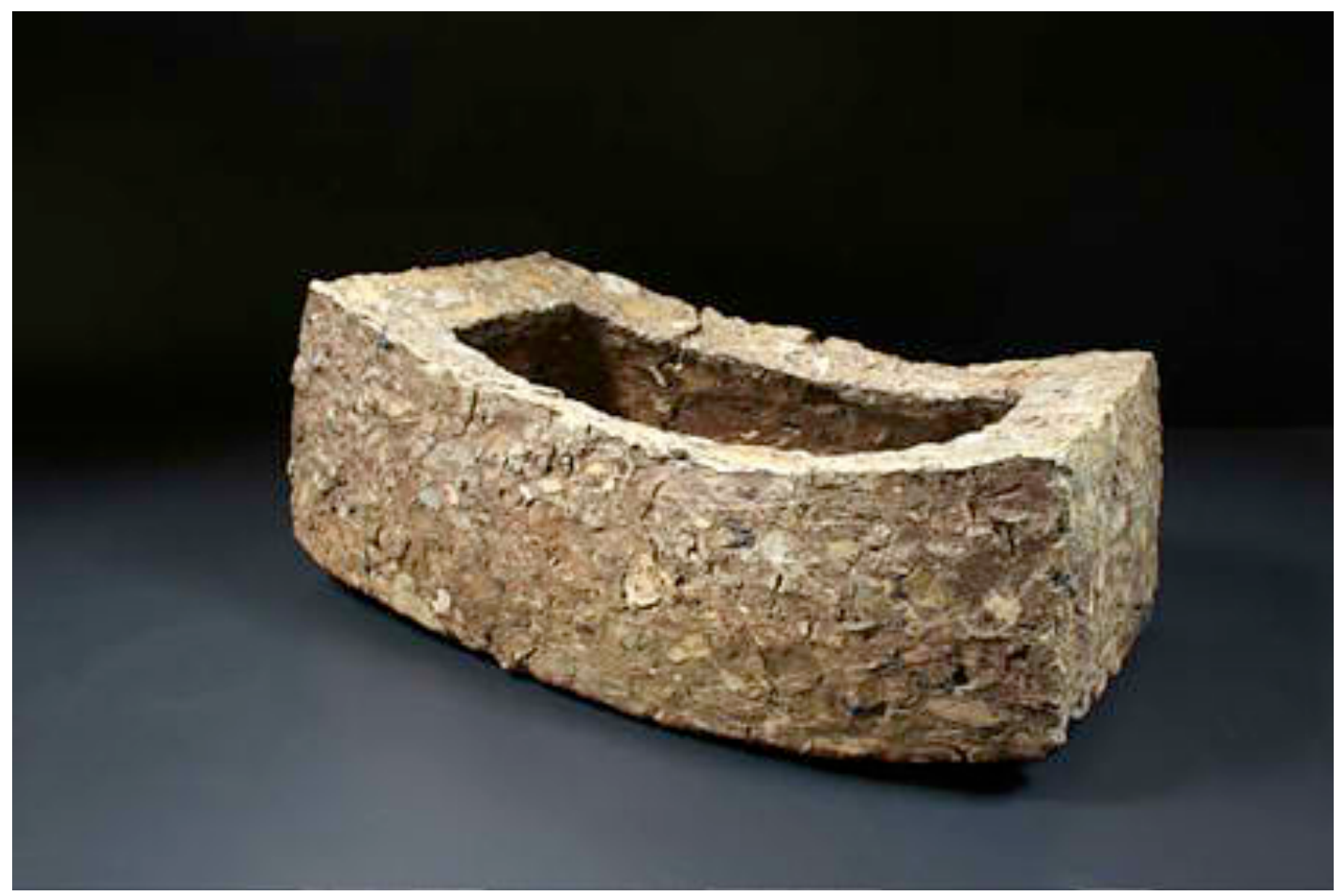

(Figure 4) Tim Rowan, Object \#9 11x16×30 in. 2007

http://www.santafeclay.com/allstar09.html 


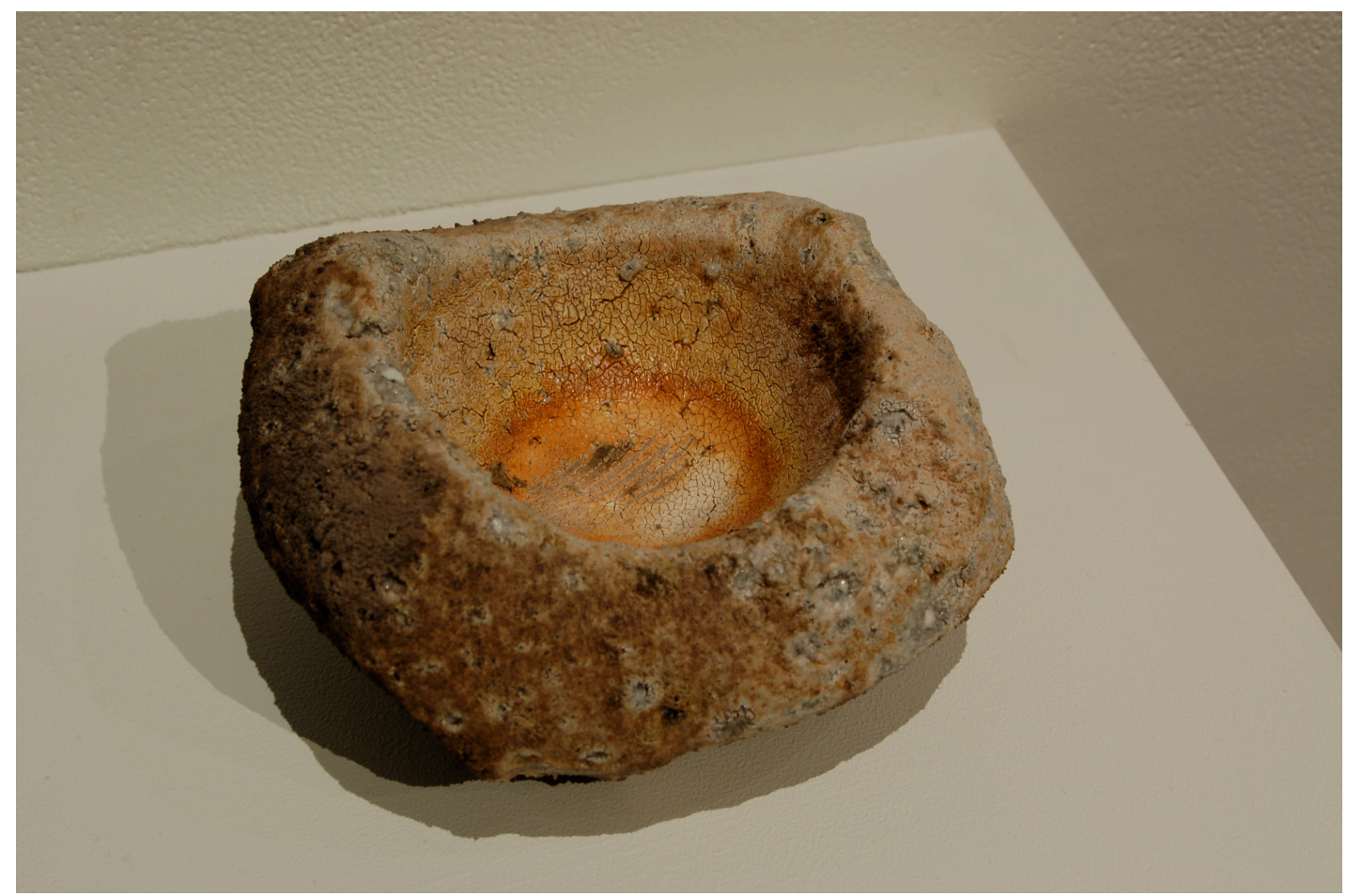

(Figure 5) Form \#122 Wood Fired, 2010, 3"x5.5"x5.5

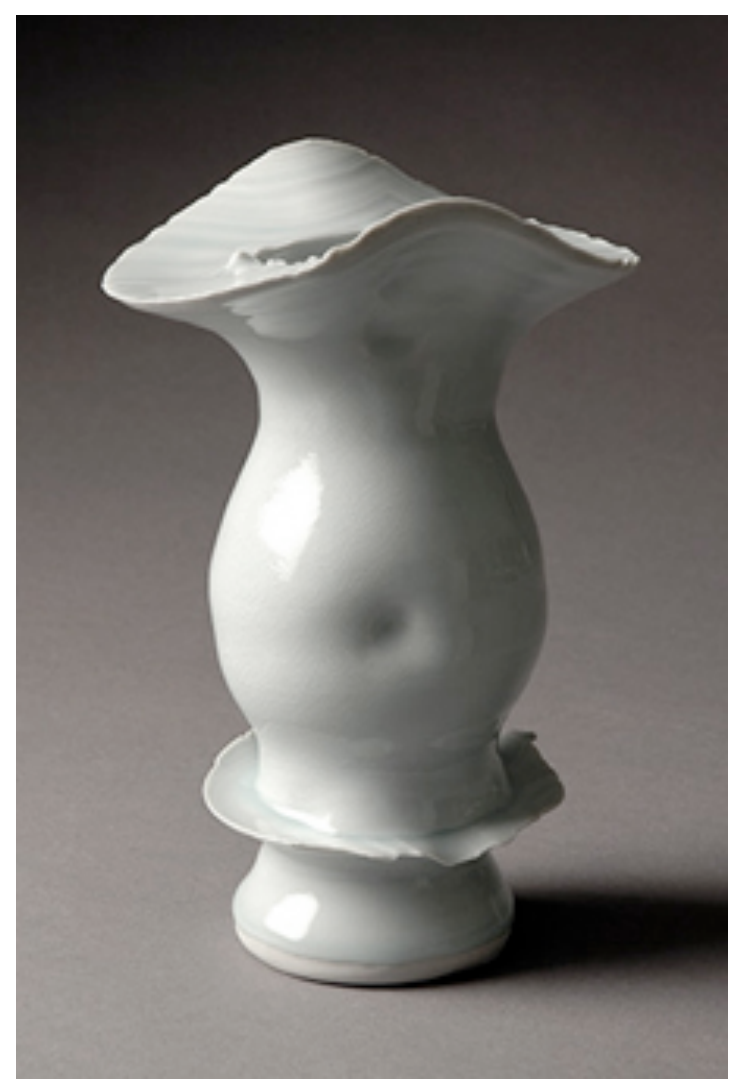

(Figure 6) Takeshi Yasuda, Porcelain Vase http://threadcountlab.blogspot.com/2010/10/takeshi-yasuda.html 


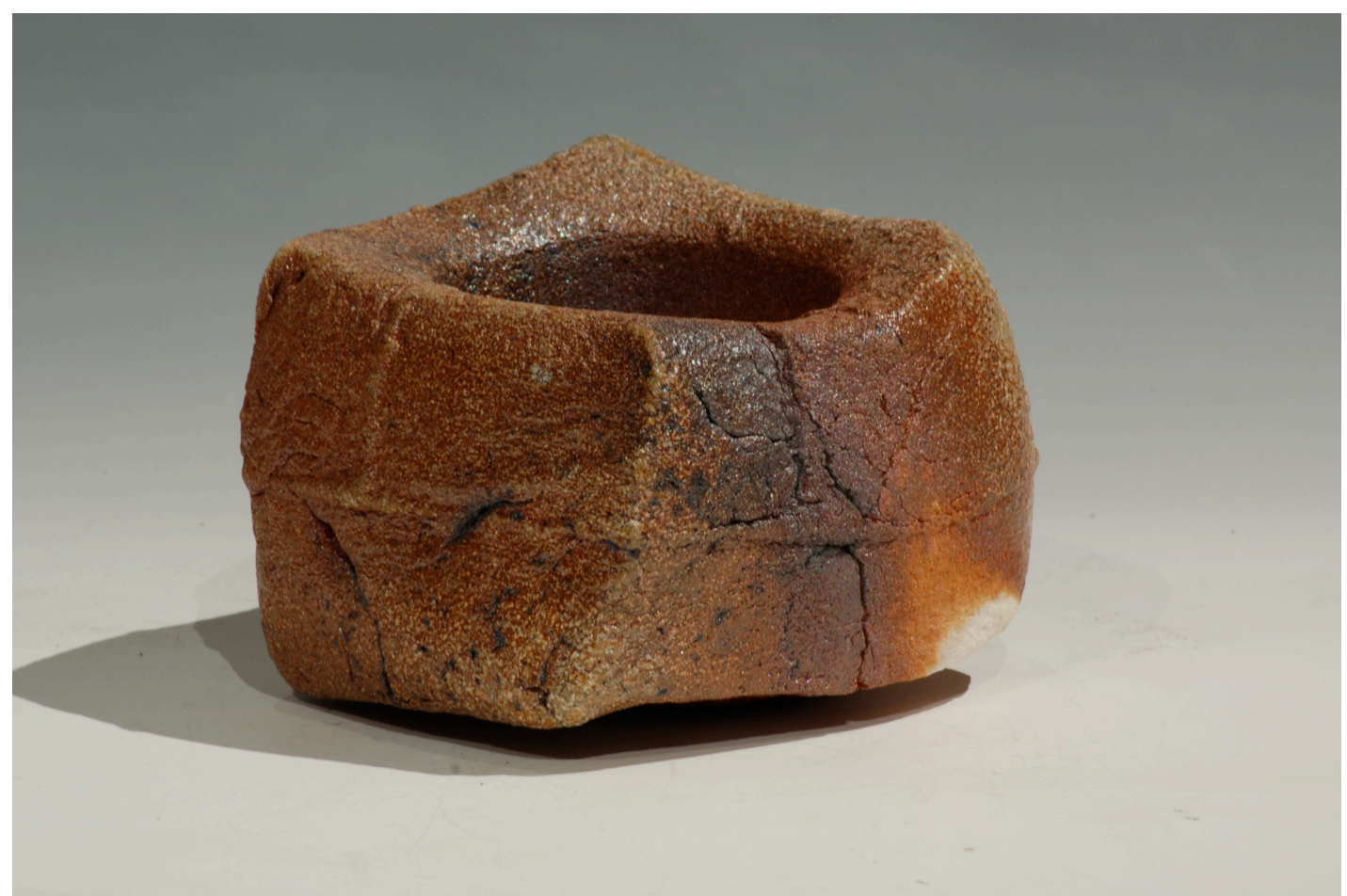

(Figure 7) Form \#280, Salt Fired, 2011, 4.5"x7”x6.5"

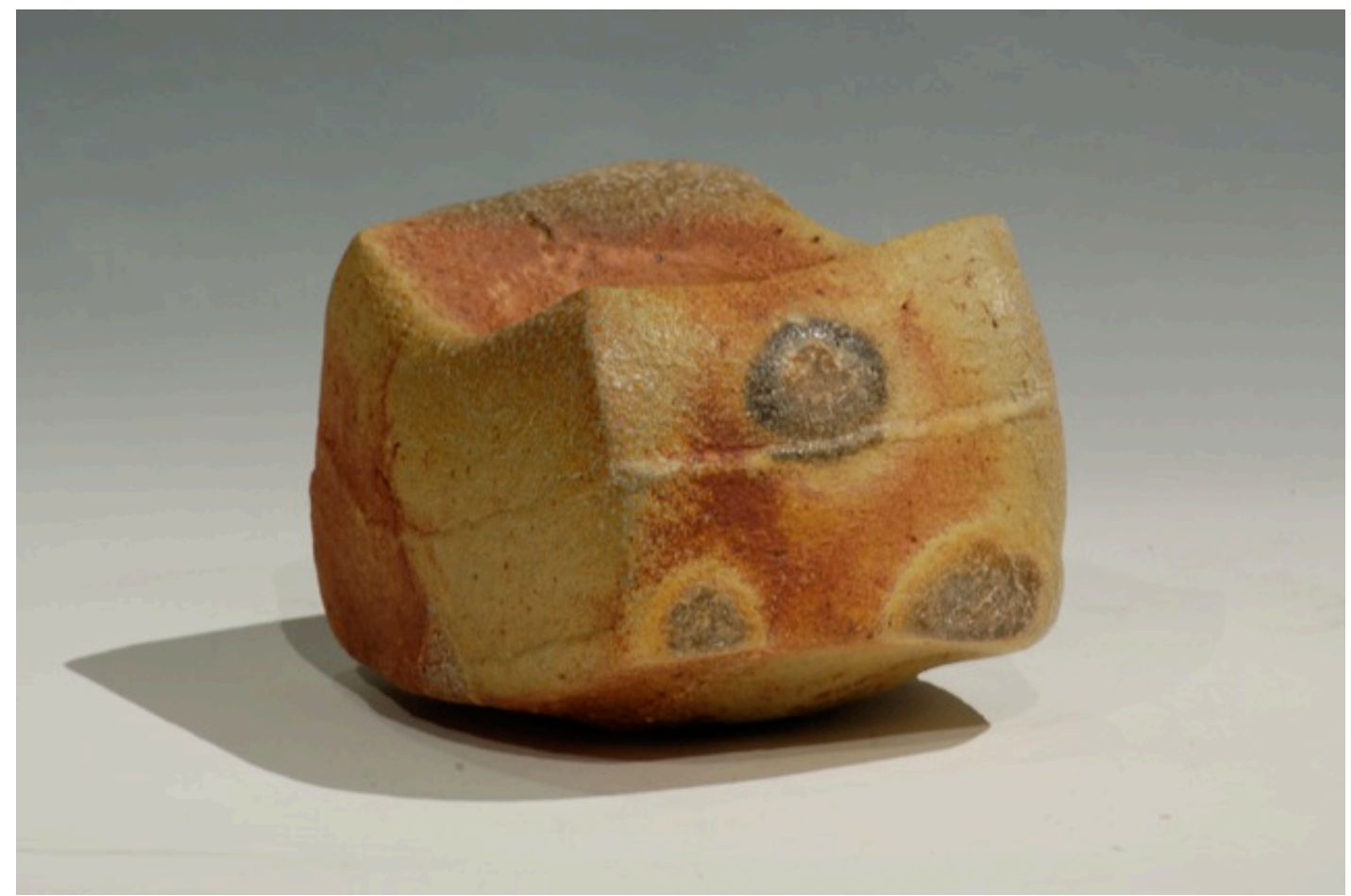

(Figure 8) Form \#193 Salt Fired, 2011, 5" x 7 1/2" x 6 1/2" 


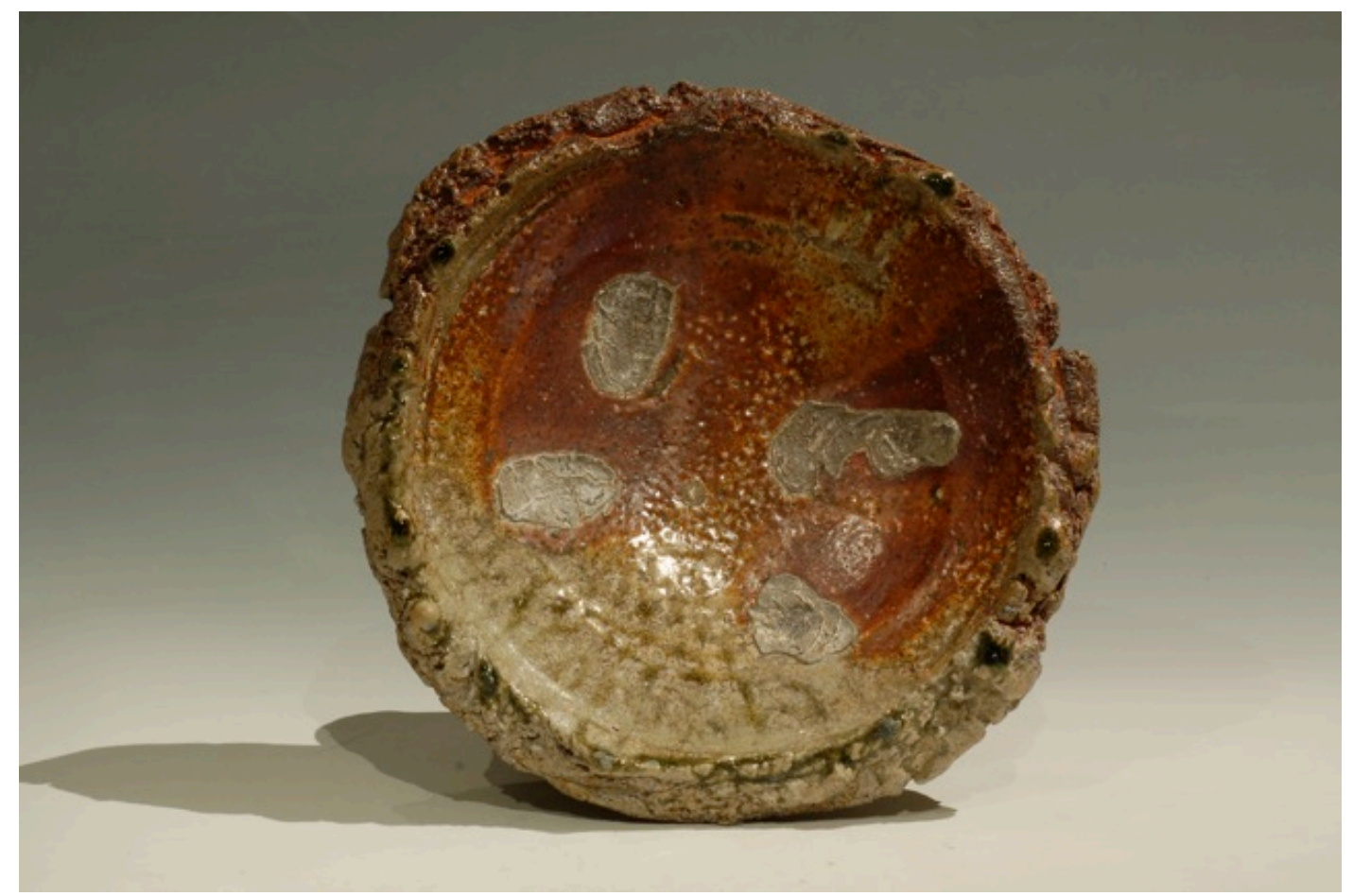

(Figure 9) Form \#22 Wood Fired, 2010, 3" x 13 1/2" x 13 1/2"

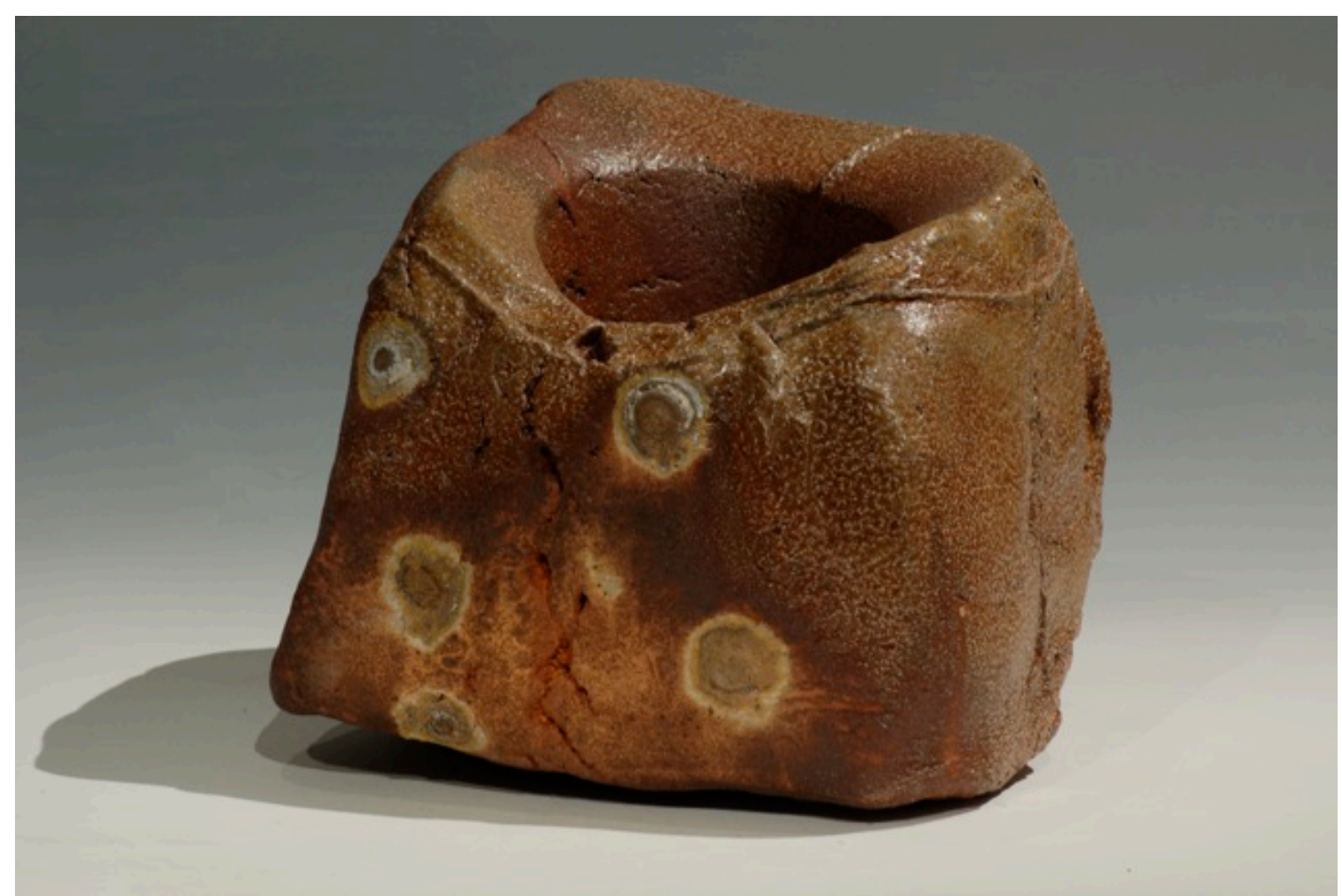

(Figure 10) Form \#341 Salt Fired, 2011, 10" x 11" x 10" 


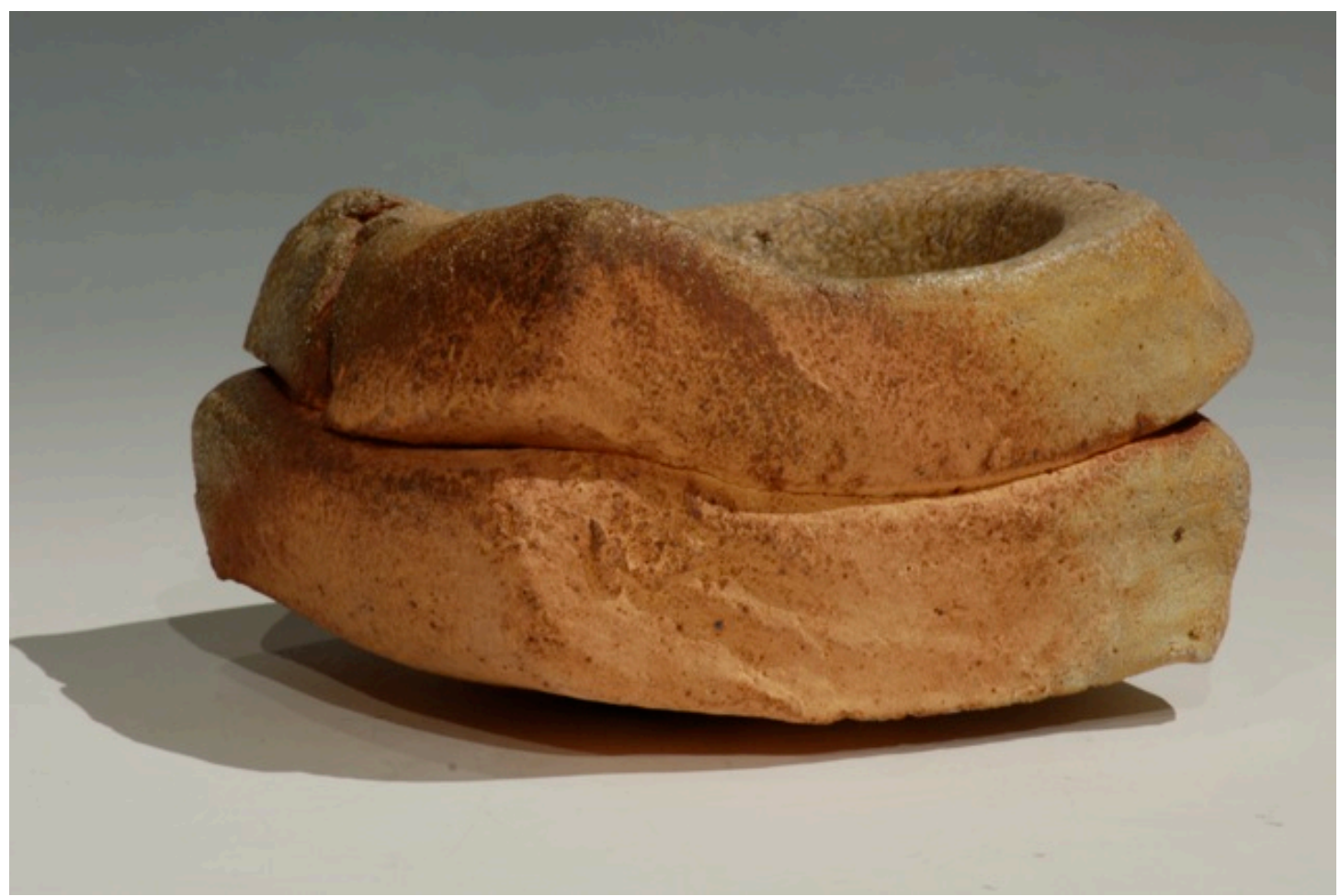

(Figure11) Form \#290 Salt Fired, 2010, 5 1⁄2" x 9" x 7 1⁄2" 


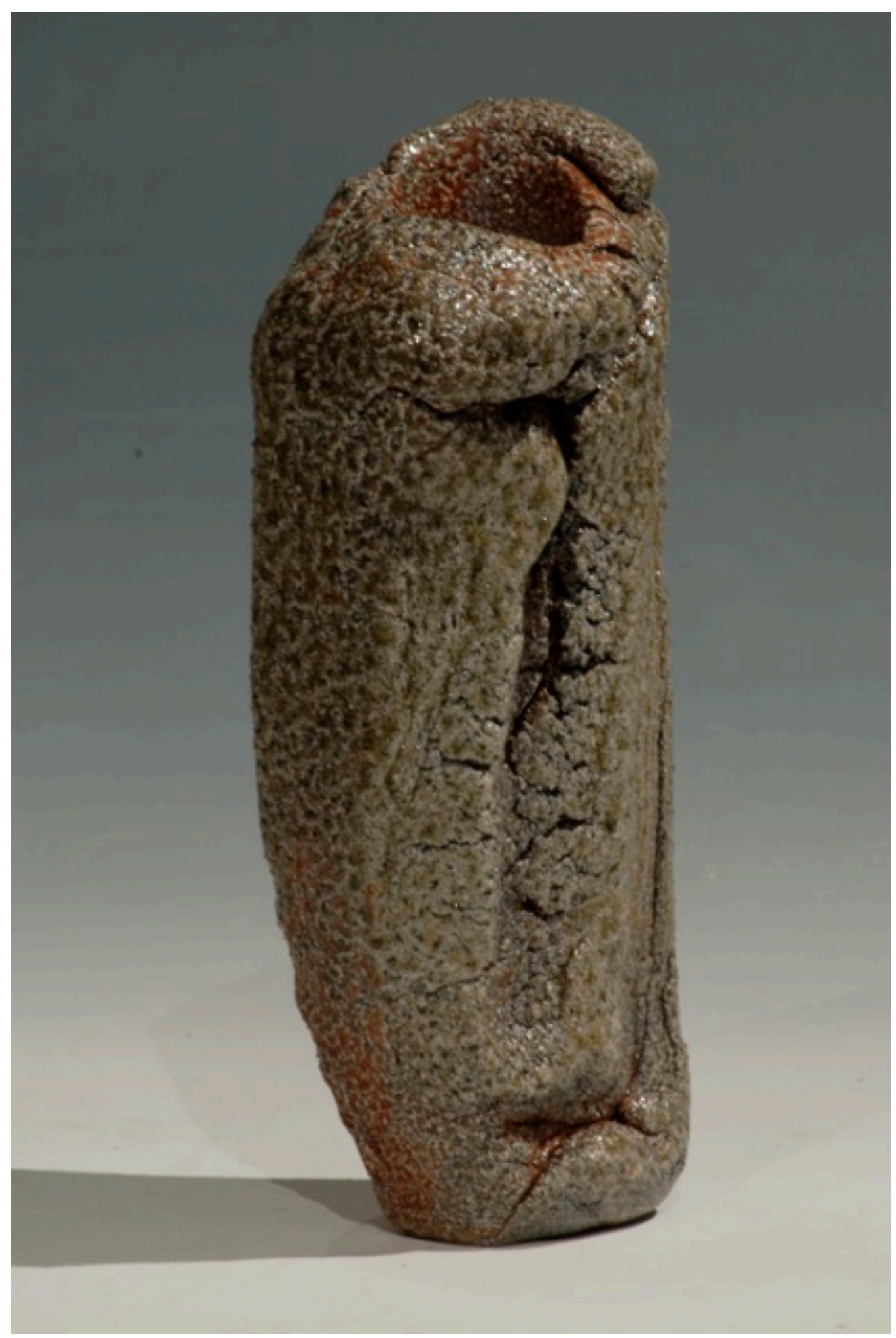

(Figure 12) Form \#342 Salt Fired, 2011, 11 3/4" x 5" x 3" 


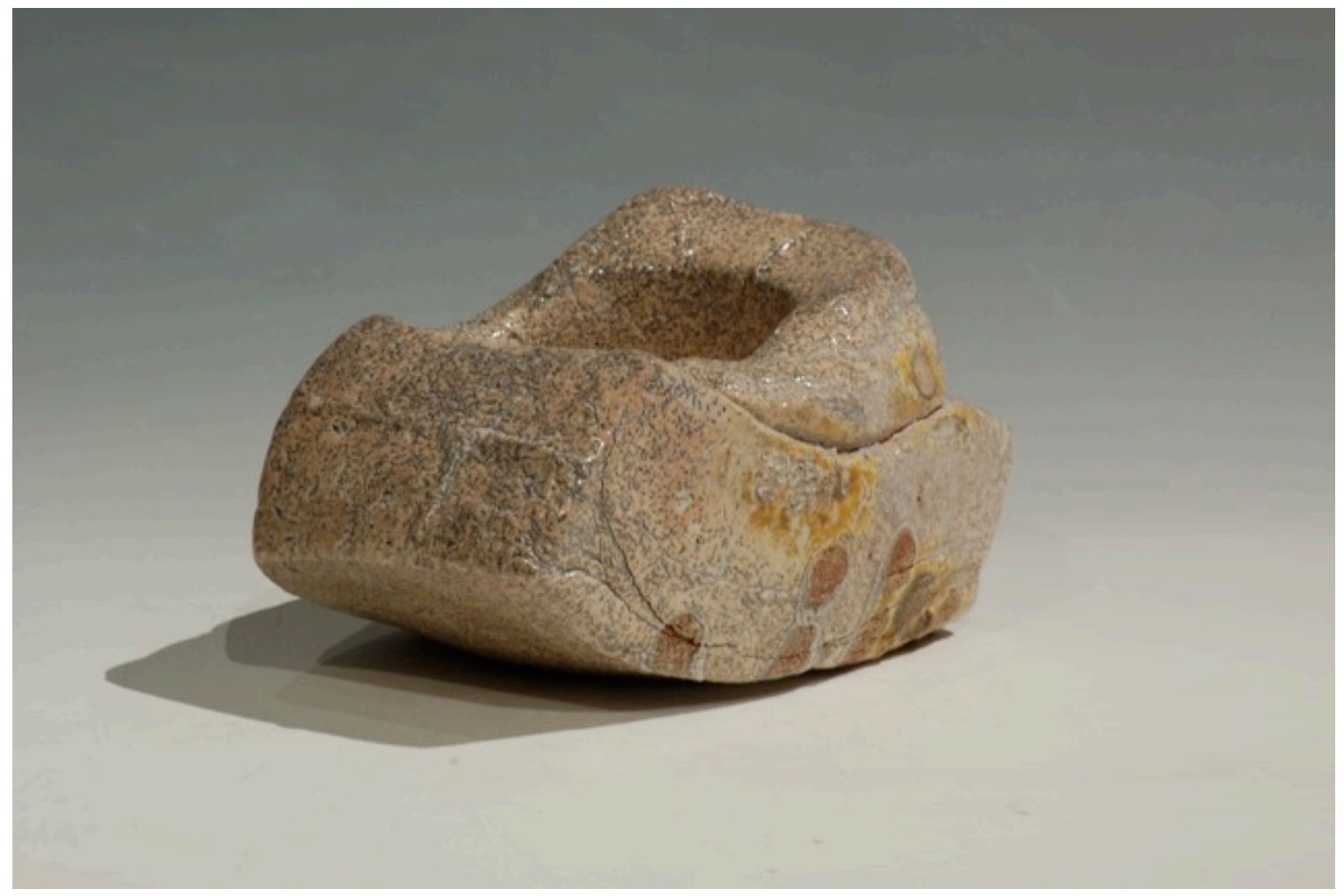

(Figure 13) Form \#287 Multi-Salt Fired, 2011, 4 1⁄2" x 8" x 6" 


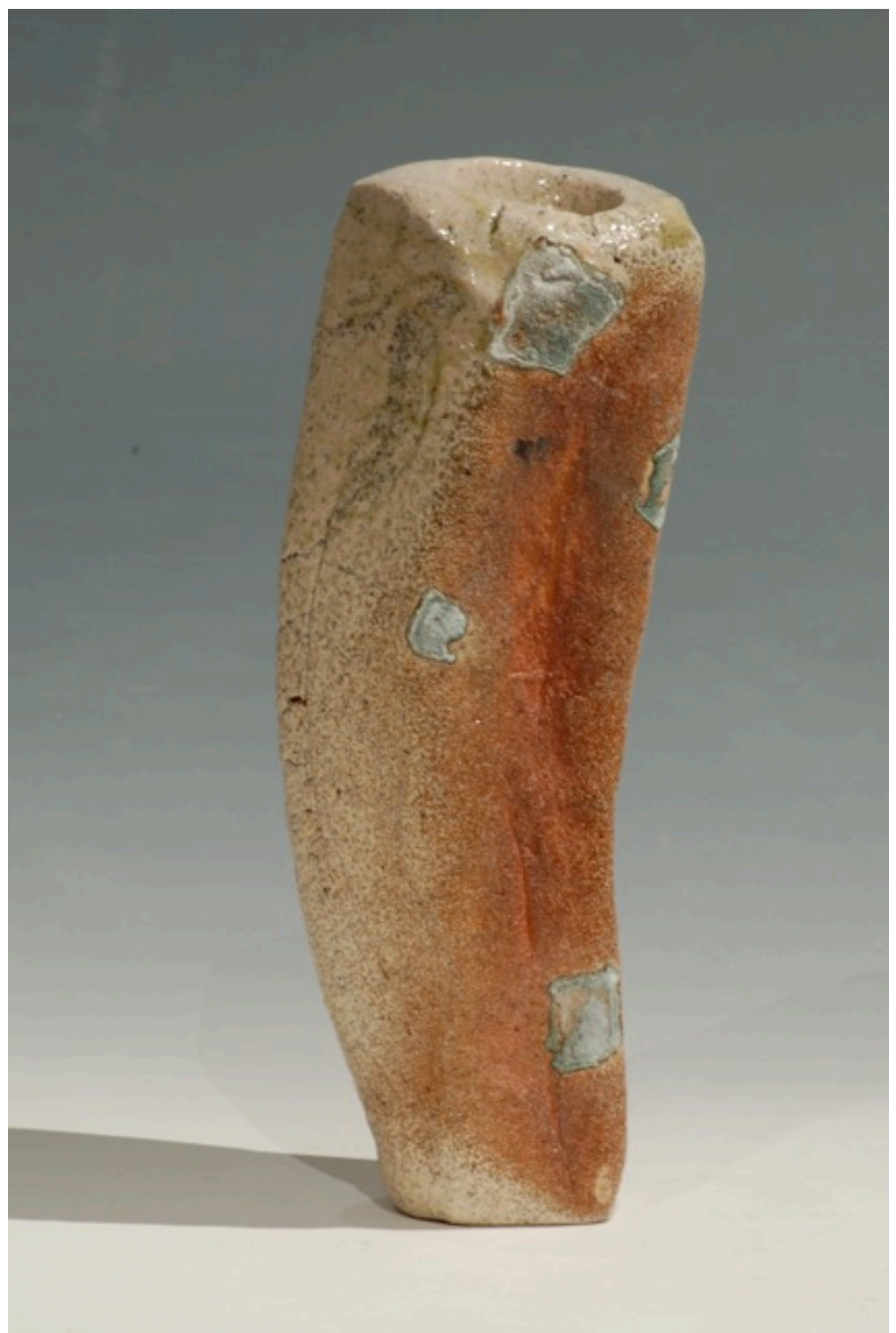

(Figure 14) Form \#311 Salt Fired, 2011, 13 " x 5 1/2" x 3 1/2" 


\section{Appendix}

- Clay Recipes

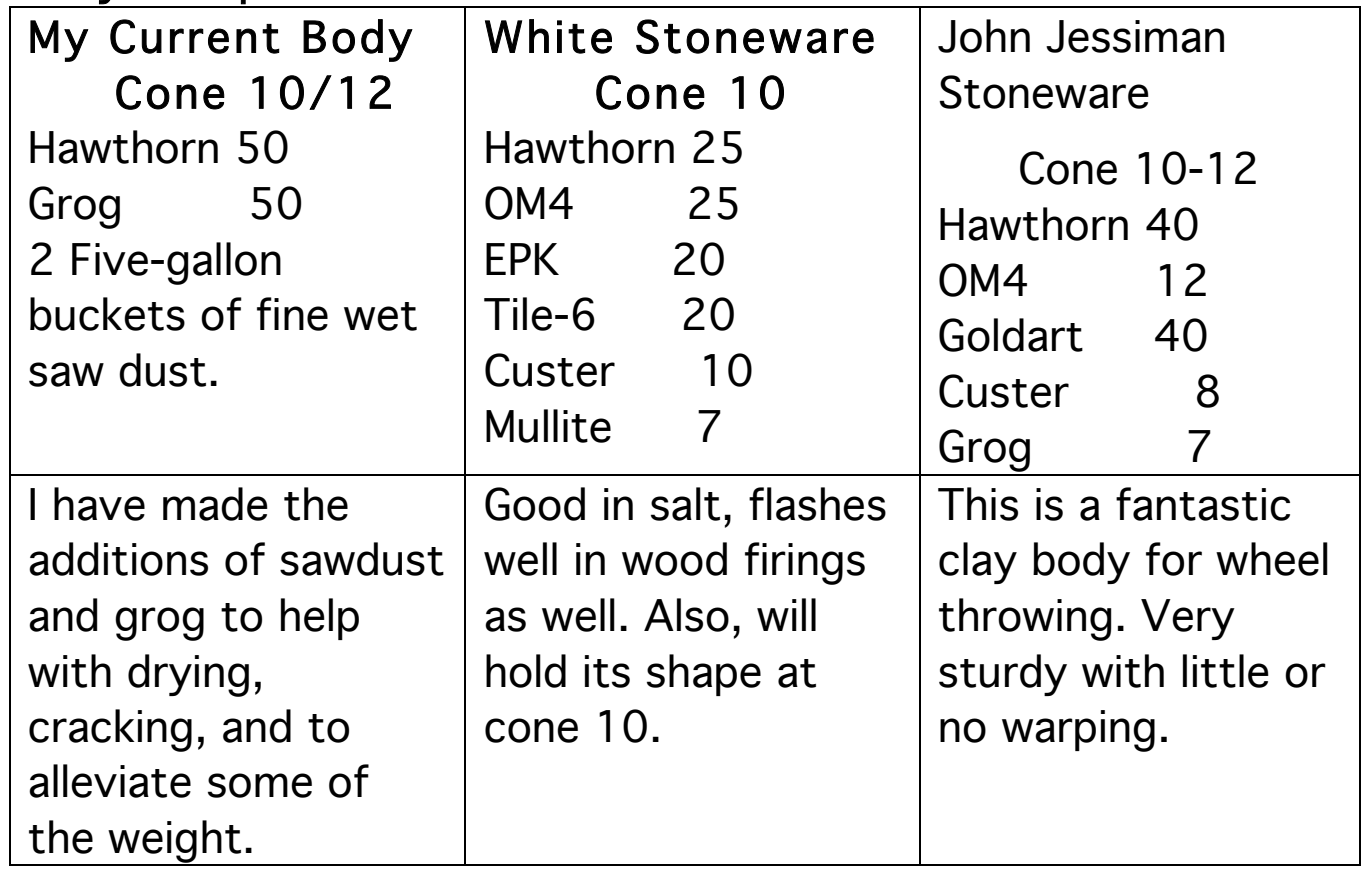

I have tried many clay bodies with mixed results. I continue to remove ingredients and adjust amounts and I have decided that the most practical way is to work with my current body and use slips to mask the body and get the results I am interested in.

\section{- Slip Recipes Cone 10/12}

\begin{tabular}{|c|c|c|}
\hline Martin Tagseth's Basic & $\begin{array}{l}\text { John Jessiman's } \\
\text { White stoneware }\end{array}$ & $\begin{array}{l}\text { Matt Long's } \\
\text { Butter }\end{array}$ \\
\hline Flasher & EPK $\quad 20$ & Grolleg 80 \\
\hline & OM4 & Borax $\quad 10$ \\
\hline Tile-6 & Silica & Zircopax 10 \\
\hline OMA $\quad 20$ & G-200 & Titanium 8 \\
\hline Neph Sy. 30 & Hawthorn $\quad 12$ & \\
\hline Spodumen 15 & Plastic Vitrox 8 & \\
\hline
\end{tabular}




\begin{tabular}{|l|l|l|}
\hline Epic & Dry wads & Wading \\
\hline EPK 45 & Plaster 50 & Kaolin 50 \\
OM4 $\quad 18$ & Whiting 50 & Aliumina \\
Whiting 18 & & \\
Neph Sy 18 & & \\
\hline Needs heavy salt & & \\
\hline
\end{tabular}

- Glaze Recipes Cone 10

\begin{tabular}{|c|c|c|}
\hline Ash and Alberta & Malcolm Davis Shino & Val Cushing's Taffy \\
\hline Albeta Slip 77.5 & Neph Sy 49.5 & Cornwall 46 \\
\hline Ash $\quad 17.5$ & F-4 Feldspar 9.8 & Whiting \\
\hline Silica & $\begin{array}{lc}\text { Kaolin } & 18.2 \\
\text { Ball Clay } & 13.8 \\
\text { Soda Ash } & 17.3\end{array}$ & $\begin{array}{lc}\text { Kaolin } & 20 \\
\text { RIO } & 4 \\
\text { Titanium } & 6\end{array}$ \\
\hline
\end{tabular}

\begin{tabular}{|c|c|c|}
\hline $\begin{array}{l}\text { Dolly's Russian } \\
\text { Hotel }\end{array}$ & $\begin{array}{l}\text { Val Cushing's } \\
\text { Tomato Red }\end{array}$ & $\begin{array}{l}\text { Val Cushing's } \\
\text { Brandy }\end{array}$ \\
\hline $\begin{array}{ll}\text { Neph Sy } & 7.7 \\
\text { F-4 Feldspar } & 53.6 \\
\text { Spodumene } & 19 \\
\text { Kaolin } & 7 \\
\text { Barnard Slip } & 7.7 \\
\text { Soda Ash } & 5\end{array}$ & $\begin{array}{lc}\text { F-4 } & 45 \\
\text { Silica } & 24 \\
\text { Whiting } & 7 \\
\text { Kaolin } & 7 \\
\text { Mag Carb } & 6 \\
\text { Bone Ash } & 11 \\
\text { RIO } & 8\end{array}$ & $\begin{array}{l}\text { Equal parts } \\
\text { Cushing's Taffy } \\
\text { \& Tomato Red } \\
\text { (Wet) }\end{array}$ \\
\hline
\end{tabular}


Bisque firing schedule for large thick pieces

\begin{tabular}{|c|c|c|c|c|}
\hline Hours & Left Burner & $\begin{array}{l}\text { Right } \\
\text { Burner }\end{array}$ & Damper & Fans \\
\hline $1-24$ & Pilot on & Off & $1 "$ & \\
\hline $24-48$ & " & Pilot on & " & \\
\hline $48-60$ & Burner .25 & “ & “ & \\
\hline $60-72$ & “ & Burner .25 & 1.5" & \\
\hline $72-76$ & Burner .5 & “ & “ & \\
\hline $76-80$ & “ & “ & “ & \\
\hline $\begin{array}{c}\text { When Red } \\
\text { heat is } \\
\text { visible }\end{array}$ & & & & $\begin{array}{c}\text { On } \\
.25 \text { air }\end{array}$ \\
\hline $80-84$ & Burner .75 & Burner .5 & “ & \\
\hline $84-88$ & “ & Burner .75 & $"$ & \\
\hline $88-90$ & “ & " & 1.25 & \\
\hline
\end{tabular}

My pots are bisque fired to cone 04. I want to give the pots strength to be tumble stacked.

Once the kiln reaches cone 04 . Block off all of the ports and allow cooling. The kiln cools for about 3 days.

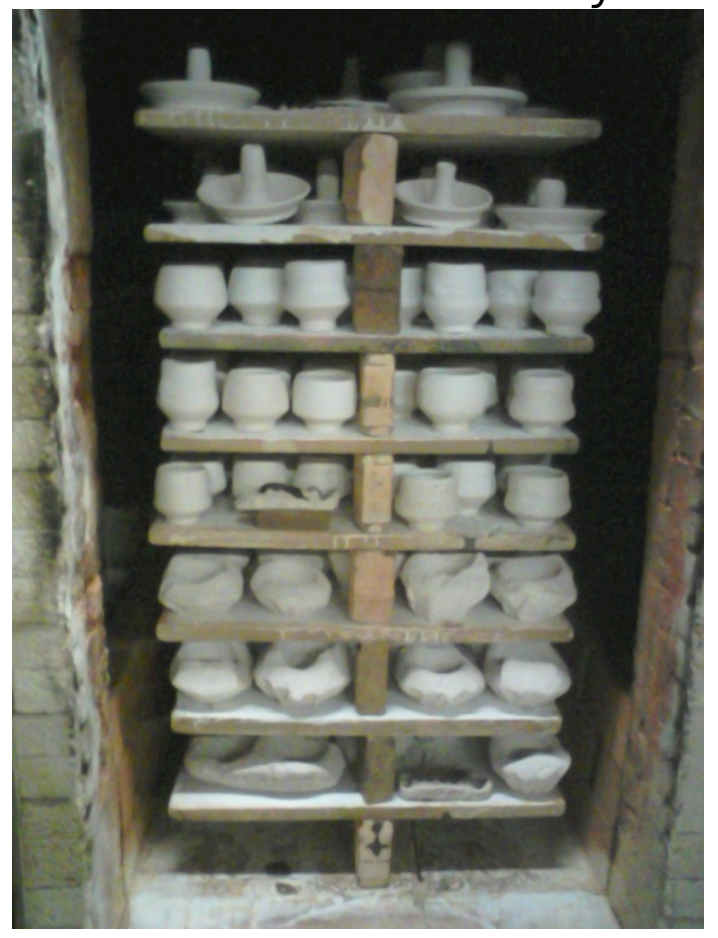

Due to the fact that I am not allowed to Bisque my work in the building because of the additions of saw dust. I have been forced to fire in the gas kilns.

When I first started fire my pots there were some cracking issues. I found that by stacking the pots tighter I could increase the thermal mass of the pots. This helps to heat them a bit slower and more even, also the cooling was slower and the pots have stopped cracking. 


\section{Wood Firing schedule}

\begin{tabular}{|c|c|c|c|c|}
\hline Hour & Temperature & Time & Damper & Notes \\
\hline 1 & 100 & & & \\
\hline 2 & 100 & & & \\
\hline 3 & 100 & & & \\
\hline 4 & 150 & & & \\
\hline 5 & 150 & & & \\
\hline 6 & 200 & & & \\
\hline 7 & 200 & & & \\
\hline 8 & 200 & & & \\
\hline 9 & 250 & & & \\
\hline 10 & 300 & & & \\
\hline 11 & 400 & & & \\
\hline 12 & 500 & & & \\
\hline 13 & 600 & & & \\
\hline 14 & 700 & & & \\
\hline 15 & 800 & & & \\
\hline 16 & 900 & & & \\
\hline 17 & 950 & & & \\
\hline 18 & 1000 & & & \\
\hline 19 & 1050 & & & \\
\hline 20 & 1100 & & & \\
\hline 21 & 1200 & & & \\
\hline 22 & 1300 & & & \\
\hline 23 & 1400 & & & \\
\hline 24 & 1500 & & & \\
\hline 25 & 1600 & & & \\
\hline 26 & 1700 & & & \\
\hline 27 & 1800 & & & \\
\hline 28 & 1900 & & & \\
\hline 29 & 2000 & & & \\
\hline 30 & 2100 & & & \\
\hline 31 & 2200 & & & \\
\hline 32 & 2200 & & & \\
\hline 33 & 2250 & & & \\
\hline 34 & 2300 & & & \\
\hline 35 & 2300 & & & \\
\hline 36 & 2340 & & & \\
\hline 37 & 2340 & & & \\
\hline 38 & 2340 & & & \\
\hline 39 & 2360 & & & \\
\hline 40 & 2380 & & & \\
\hline 41 & $\begin{array}{l}\text {-Close kiln up pull } \\
\text { passives shut } \\
\text { damper } \\
\text { Seal up all openings } \\
\text { with clay }\end{array}$ & & & \\
\hline 42 & Fire Down till 1400. & & & \\
\hline
\end{tabular}

* This firing schedule is designed to heat slowly to prevent damage. 


\section{Salt Firing Schedule}

\begin{tabular}{|l|l|l|l|l|}
\hline Hour & Temperature & Gas & Damper & Notes / Fans \\
\hline $\begin{array}{l}\text { Pre-heat } \\
8 \text { hrs }\end{array}$ & & Pilots only & 1 " & Pilots only \\
\hline 1 & & Eighth on & & Left burner \\
\hline 2 & & Eighth on & & Right burner \\
\hline 3 & Quarter on & & $\begin{array}{l}\text { Left burner/ } \\
\text { Fans on }\end{array}$ \\
\hline 4 & Quarter on & $2.5 ”$ & $\begin{array}{l}\text { Right burner } \\
\text { B. reduction/ } \\
\text { Fans at } \\
\text { quarter open }\end{array}$ \\
\hline 5 & & Half on & 3 F & Left burner \\
\hline 6 & Half on & & Right burner \\
\hline 7 & $\begin{array}{l}\text { Three } \\
\text { quarters on }\end{array}$ & & Fan at half \\
\hline 8 & $\begin{array}{l}\text { Three } \\
\text { quarters on }\end{array}$ & & \\
\hline 9 & Full on & & Half open \\
\hline 10 & Full on & & Half open \\
\hline 11 & $\begin{array}{l}\text { Salt when } \\
\text { cone } 9 \text { is at } \\
\text { down. }\end{array}$ & & & \\
\hline 12 & 2340 F & & & $\begin{array}{l}\text { Close off kiln, } \\
\text { shut off fans, } \\
\text { and close } \\
\text { damper }\end{array}$ \\
\hline & & & &
\end{tabular}




\section{Bibliography}

Britt, John. 2004. The Complete Guide to High-Fire Glazes

Cardew, Michael. Pioneer Pottery. London: A \&C Black.2002.

Chambers, Ruth; Gogarty, Amy; Perron, Mireille; 2007. Utopic Impulses:

Contemporary Ceramics Practice. Ronsdale Press B.C. Canada

Chattopadhyay, Collette."Peter Voulkos: Clay, Space, and Time," International Sculpture Center, Http://www.Sculpture.org/documents/scmag01/march01/voulkos /voulkos.stml (accessed April 26th, 2011)

Coakes, Michelle. 1998. Creative Pottery. Rockport Publishers Inc.Gloucester, Massachusetts

“Joe Pintz at MudFire," MudFire. http://www.mudfire.com/joe-pintz-constructed.htm (accessed April 26, 2011)

Hopper, Robin. 2000. Functional Pottery: Form and Aesthetic in Pots of Purpose. Kruase Publications 700 East Street lola, Wisconsin.

Leach, Bernard. 1976. A Potter's Book. London, England: Clays Ltd., St.Ives Place.

Nelson, Glenn, C. 1966. Ceramics: A Potter's Handbook. Holt, Rinehart, And Winston, Inc., New York

Olsen, Frederick L. 2001. The Kiln Book. 3d ed. lola, WI: Krause Publications. 
Peterson, Susan. 2004. The Craft and Art of Clay. Princeton Hall Inc. Laurance King Publishing Ltd.

"Peter Voulkos," Ground Floor Sculpture. http://www.groundsforsculpture.org/c_pvoulkos.htm (accessed April 26, 2011)

Rawson, Phillip. 1971. Ceramics. Ely House, London, England; Oxford University Press.

Risatti,Howard. 2007. A Theory of Craft. The University of North Carolina Press

Rhodes, Daniel. 1973. Clay and Glazes for the Potter. Radnor, Pennsylvania: Chilton Book Company.

“Takeshi Yasuda," Takeshi Yasuda, http://takeshiyasuda.com/Takeshi_Yasuda_CV.pdf (accessed April 26, 2011)

"Tim Rowan Resume + Artist Statement," Tim Rowan, http://www.timrowan.com/index.html (accessed April 26, 2011) 


\section{CV}

allwalksofclay@yahoo.com

EDUCATION:

West Virginia University; Morgantown, WV Graduate Program

08-2011

West Virginia University; Morgantown, WV Special Student

$07-2008$

Jingdezhen Ceramic Institute, Jingdezhen, PR China

Fall 2009

Bethany College; Bethany, WV Bachelor of Arts: Visual Art

00-2006

"Distinction" on Senior Written and Oral Comprehensive Exam

Regents College; London, England

Spring 2002

INTERNATIONAL EXHIBITIONS:

Gallery 1, Jingdezhen, China.

2009

No. 9 Gallery, Jingdezhen, China

2009

$\mathrm{JCl} / \mathrm{NCECA}$, Robert Anderson Gallery Jingdezhen, China

2008

NATIONAL EXHIBITION:

Strictly Functional Pottery National, Lancaster, PA

2009

SOLO EXHIBITIONS:

“Polar Opposites" Zen Clay Gallery, Morgantown, WV 2011

MFA Thesis Exhibition, Messaros Gallery, WVU 2011

Bethany College Senior Art Exhibit; Bethany, WV 2005

\section{EXHIBITIONS:}

WVU Student Exhibition, Zen Clay Gallery

2011

Bethany College Alumni Show, Bethany, WV

2010

Graduate Group Exhibition, Morgantown, WV

2010

Graduate Group Exhibition, Pittsburgh, PA

2010

Bethany College Alumni Show, Bethany, WV

2008

Bethany College Fall Annual; Bethany, WV Honor Mention 2008

WVU Student Exhibition, Zen Clay Gallery 2008

Slippery Rock University 2008

Steubenville Art Association Annual Spring Exhibition (Merit Award) 2007

Steubenville Art Association Annual Spring Exhibition (Merit Award) 2006

Steubenville Art Association Annual Spring Exhibition (Merit Award) 2005

Bethany College Student Art Exhibition (Merit and Honor Mention) 2005

Bethany College Fall Annual; Bethany, WV 2003

"I Dream of Clay" Exhibition - Wheeling, WV Artisan Center 2003

Ground Floor Gallery Invitation Exhibition - Wheeling, WV 2002

TEACHING EXPERIENCE:

Adjunct Professor, Bethany College, Ceramics 2011

Ceramics Instructor / West Virginia University 2011

Drawing Instructor/ West Virginia University 2010

RELATED EXPERIENCE:

Juror. Bethany College, Fall Annual art show 2010 
Slide Room Assistant. WVU 2010

Secretary WVU Clay Cub $\quad 10 / 2011$

Gallery Assistant. WVU 08/2009

Studio Technician. WVU 08/2009

Self-Employed: Pottery Business (All Walks of Clay) 06/2007

Lab Proctor / Technician Bethany College (Ceramics) 02/2005

Wheel throwing demonstrations for college functions $\quad 02 / 2005$

RELATED SKILLS:

- Military Leadership

TECHNICAL SKIILLS:

- Slip casting/Mold making

- Glaze Calculation

- Kiln building

- Carpentry/ Welding

PRESENTATIONS:

NCECA Graduate Presentations, Philadelphia, Pennsylvania 2010

Guest Lecturer Pottery Workshop, Jingdezhen, PR China 2009

NCECA Graduate Presentations, Phoenix, Arizona 2009

NCECA Graduate Presentations, Pittsburgh, Pennsylvania 2008

CONFRENCES AND WORKSHOPS:

WVU Workshop-Birdie Boone Morgantown WV. 2011

NCECA Philadelphia, Pennsylvania 2010

WVU NCECA Pre-conference; Philadelphia: Morgantown WV 2010

NCECA Phoenix, Arizona 2009

Cub Creek Foundations Workshop (Judith Duff) Appomattox, VA 2009

NCECA Shared Journeys Jingdezhen China 2008

Slippery Rock University- David MacDonald Workshop 2008

NCECA Pittsburgh, Pennsylvania 2008

WVU NCECA Pre-conference Pittsburgh; Morgantown WV 2008

NCECA Louisville, Kentucky 2007

\section{OTHER WORK EXPERIENCE:}

Bethany College, Adjunct Professor

2011

West Virginia University, Graduate Assistant

$08 / 2011$

Wal-Mart Distribution Center, Order Filler

2007

US Army Reserves, Sergeant

$99 / 2007$

Pro Builder Supply, Outside Sales

$06 / 2007$

Bethany College, Admissions Counselor

2006 